Received: 20 June 2020 Accepted: 13 November 2020

DOI: https://doi.org/10.33182/bc.v10i2.1051

\title{
Child soldier realty in Uganda: International law and reintegration
}

\author{
Zeynep Banu Dalaman ${ }^{1}$ and Türkan Melis Parlak²
}

\begin{abstract}
The use of children who have been most exposed to the destructive effects of wars for various military activities has been seen throughout history. Child soldiers are involved in civil wars and conflicts in many countries, especially in Africa, without discrimination. Even if the participation of 15-year-olds in the Army is accepted as a war crime by the United Nations, some 300,000 children are actively involved in wars today. The key to child soldiers is the reintroduction and retraining of these children. However, what should be mentioned here is that these children are guilty? Or a victim? In this article, the child soldier problem will be discussed from two angles. First, the effectiveness of the decisions taken to prevent criminal organisations and states from committing this crime to recruit child soldiers within the framework of international law rules will be discussed. Secondly, based on the example of Uganda, the programs prepared by the international community for the reintegration of former child warriors to society will be analysed.
\end{abstract}

Keywords: child soldiers; international crime; integration; Uganda; Lord's Resistance Army.

\section{Introduction}

silent enim legis inter arma ${ }^{3}$

Wars, conflicts, and civil wars are as old as human history. It is always the civilians who suffer the most during these conflicts than combatants, and especially children and women have always been the most affected groups. It is seen throughout the history that the children who are exposed to situations like wars, were later used for various military activities. Child soldiers carry a heavy burden of being forced to being armed and participate in wars directly and indirectly since ancient times. Children participate in civil wars and battles worldwide, particularly in Africa, without gender distinction. Children's involvement in the military has also constituted public perception; in the mid20th century, child soldier issue has been one of the most discussed topics with the development of legal humanism. Especially with the constitution of the International Criminal Court, the use of child soldiers has been banned and sentenced to legal enforcements. Uganda's Lord's Resistance Army(LRA) is one of the malevolent examples of child soldier abuse; they abduct children by pulling out guns and then using them (Karakaya, 2018:32). Child soldiers were used not only by the mentioned organisation but also used by the Ugandan government to fight against this organisation. According to the UN (2017), around 115,000 children have been discharged from the armed forces worldwide dated from 2000. As these children are discharged from these terrorist

\footnotetext{
${ }^{1}$ Dr Zeynep Banu Dalaman, Istanbul Ayvansaray University, Department of Political Science and International Relations, Turkey. E-mail: banudalaman@ayvansaray.edu.tr.

${ }^{2}$ Türkan Melis Parlak, Özyegin University, Istanbul and Istanbul Aydın University, Turkey. E-mail: melisparlak@aydin.edu.tr.

3 "In times of war, the law falls silent"
} 
organisations, an unknown number of traumatic and criminal incidents raise questions nearly how these children should be reintegrated into community later joining. International organisations and national governments remain undetermined as to whether these children should be treated as war criminals or victims for their crimes, let alone who finances rehabilitation programs. If not rehabilitated decently, it can become a menance to public safety. This research will analyse based on the example of Uganda, the international legal dimension of the child soldier issue and the reintegration of these children into society will be addressed by the global resolution.

\section{Basic Principles: Combatant, Child and Child Soldiers Concept}

Law of armed conflicts is based on two legs and three basic principles. These two legs are; jus in bello and jus ad bellum ${ }^{4}$, and three basic principles must be taken into consideration when determining the two legs; proportionality, military necessity and avoiding unnecessary pain. Jus in bello regulates the rules in conflict, and in order to keep the balance of principles, jus in bello's fundamental principle, the distinction of combatants and civilians in a conflict must be applied (ICRC, 2019). Combatants directly have the right to engage in armed conflicts (Kocatepe, 2009: 68). Unless they take armed action against international criminal laws, they are not get judged and are treated as prisoners of war if ever captured by aggressor forces. Combatants are obliged to separate themselves from the civilians. Combatant status first appeared in the additional protocol of 1907 Hague Conventions. Following the first article of the additional protocol, in order to get the combatant status, a responsible official must supervise the candidate, they must carry their guns openly, must have a stable and visible at a distance sign, and they should act according to customary rules. This judgement was repeated in the 4th Article of the 1949 Geneva Convention relative to the Treatment of Prisoners of War. Spies, legionaries and saboteurs are not considered as combatants. According to Article 43 of Additional Protocol 1 to the Geneva Conventions in 1977;

"1. The armed forces of a Party to a conflict consist of all organised armed forces, groups and units which are under a command responsible to that Party for the conduct of its subordinates, even if that Party is represented by a government or an authority not recognised by an adverse Party. Such armed forces shall be subject to an internal disciplinary system, which shall enforce compliance with the rules of international law applicable in armed conflict.

2. Members of the armed forces of a Party to a conflict are combatants, that is to say, they have the right to participate directly in hostilities.

3. Whenever a Party to a conflict incorporates a paramilitary or armed law enforcement agency into its armed forces it shall so notify the other Parties to the conflict."

\section{According to Article 48 of Additional Protocol 1;}

"In order to ensure respect for and protection of the civilian population and civilian objects, the Parties to the conflict shall at all times distinguish between the civilian population and combatants and between civilian objects and military objectives and accordingly shall direct their operations only against military objectives."

\footnotetext{
${ }^{4}$ Jus ad bellum refers to the conditions under which one may resort to war or to force in general; jus in bello governs the conduct of belligerents during a war, and in a broader sense comprises the rights and obligations of neutral parties as well (Kolb, 1997: 553). 
Mutual Article 3 of the Geneva Convention clarifies the distinction between combatants and civilians. According to Article 3;

"Persons taking no active part in the hostilities, including members of armed forces who have laid down their arms and those out of combat by sickness, wounds, detention, or any other cause, shall in all circumstances be treated humanely, without any adverse distinction founded on race, color, religion, faith, sex, birth or wealth, or any other similar criteria."

Another topic to be discussed is children. Childhood is the age span from spiritual and physical birth to adolescence. Turkish Criminal Law (TCL) defines a child as any person under the age of 18. United Nations Convention on the Rights of the Child also defines a child as any person until the age of 18. However, both regulations did not touch upon the beginning of childhood.

Any person under the age of 18 who directly or indirectly serves in armed forces or associated with any political organisation is defined as a child soldier. A person does not need to attend armed conflicts to be accepted as a child soldier; child soldier notion is accepted when a child is directly(combatant) or indirectly (observer, messenger, sex slave, etc.) appears in an armed conflict. Age limits for the military, as mentioned in International Conventions are below:

Table 1. Age limits for the military in International Conventions

\begin{tabular}{lcc}
\hline & Conscription & Voluntary \\
\hline $\begin{array}{l}\text { Convention on the Rights of the Child, Optional Protocol to the } \\
\text { Convention on the Involvement of Children in Armed Conflicts } \\
(2000)\end{array}$ & 18 & 16 \\
\hline African Charts on the Rights and Welfare of the Child (1990) & 18 & 18 \\
\hline Convention on the Rights of the Child (1989) & 15 & 15 \\
\hline Additional Protocols 1 and 2 to the Geneva Conventions in 1977 & 15 & 15 \\
\hline The Special Court for Sierra Leone (2002) & & 15 \\
\hline Rome Statute of the International Criminal Law (1998) & 15 \\
\hline
\end{tabular}

Based on explained reasons, it is common that children are being used for military purposes and today, the number is more than 300.000 children (ILO, 2013: iii). According to Human Rights Watch data, the youngest child soldier is eight years old. Children are used as soldiers for several reasons (Kekevi et al., 2016: 487): They are more affordable than adult soldiers and they are easy to manage and do as they are told. To create a social perception of the opponent is fighting against children and labeling them as "brutal people" and to create an ethical dilemma for the opponent are the psychological pretexts for the offenders. These criminals prefer children using the fact that not only children are not subject to criminal sanctions, or they get off with light sentences, but also children will arouse less suspicion than adults (Aydin et al., 2010: 18). These organised crime groups give the impression of "women and children fighting together" by paramilitary organisations and encourage the participation of adults by showing how brave children are.

According to a report, child soldier amount doubled in the Middle East in 2019. The UN has defined fourteen countries where children have been majorly used as soldiers. These countries are Afghanistan, Colombia, the Central African Republic, the Democratic Republic of the Congo, Iraq, Mali, Myanmar, Nigeria, the Philippines, Somalia, South Sudan, Sudan, Syria, and Yemen (Middle 
East Institute, 2020). The use of child soldiers also happens in conflict regions as a part of terrorist groups. The most attention-grabbing group was the Islamic State of Iraq and Syria (ISIS, latterly changed their name as Islamic State) who declared a caliphate in 2014. It is challenging to know the exact number of children is currently involved in ISIS, with approximately 700,000 children under its control. Went by name of the "Cubs of the Caliphate," an forecasted 1,100 children between the ages of 8-15 were brainwashed to radical Islamist militant group (Al Ibrahim, 2020). ISIS brainwashes and desensitising children to violence to form the character of the 'jihadi junior' capable of sniping, fighting, beheading, executing spies and even carrying suicide bombings. ISIS visual propaganda also promotes the image of the child victim, giving itself the legitimacy to respond and take revenge from its 'enemies.' The method of using videos and internets shows that ISIS has created a new wave in using child soldiers for their purposes While this children called "cubs" were also emphasised in a sequence of propaganda videos released to the internet for spread terror and enhance the enrollment of foreign combatants. ${ }^{5}$ Most ISIS children now live in refugee camps in Iraq, where criminal responsibility begins at the age of nine, with dozens of children on trial even though they have been abused. (Middle East Institute).

\section{Child Soldier Use According to International Law}

International Law is continuously improving since it is an area of law with a new set of rules made after significant disasters (Topal, 2009: vii). Thus, international community put forward legal arrangements in International Law to avoid the use of children as soldiers. Since the Second World War, many legal agreements, protocols and conventions have been created to punish the use of child soldiers in conflicts. ${ }^{6}$

1949 Geneva Conventions are counted as the first written enactment on the protection of children in international law and also a touchstone for humanitarian law. According to Article 14 of the Fourth Geneva Convention, one of the four treaties of the Geneva Conventions and also referred as the Convention relative to the Protection of Civilian Persons in Time of War, children under 15 are put under special protection by creating safety and healthcare zones for them as mentioned below:

"In time of peace, the High Contracting Parties and, after the outbreak of hostilities, the Parties thereto, may establish in their own territory and, if the need arises, in occupied areas, hospital and safety zones and localities so organised as to protect from the effects of war, wounded, sick and aged persons, children under fifteen, expectant mothers and mothers of children under seven."

Article 77 of the second part of Additional Protocol 1 to the Geneva Conventions in 1977 provides exceptional protection for children and child soldiers. According to Article 77:

\footnotetext{
${ }^{5}$ See Al İbrahim's article for a more detailed study on "cubes of caliphate"

${ }^{6}$ Geneva Conventions (1949), Additional Protocols to the Geneva Conventions (1977), Convention against Torture and Other Cruel, Inhuman or Degrading Treatment or Punishment (1984), UN Convention on the Rights of the Child (1989), African Charter on the Rights and Welfare of the Child (1990), Resolution on the Plight of African Children in Situations of Armed Conflict (1996), Cape Town Principles (1997), European Parliament: Resolution on Child Soldiers (1998), Berlin Declaration on the Use of Children as Soldiers (1999), Montevideo Declaration on the Use of Children as Soldiers (1999), Maputo Declaration on the Use of Children as Soldiers (1999), The Optional Protocol to the Convention of the Rights of the Child on the Involvement of the Children in Armed Conflict (2000), The Organization of American States' Resolution on Children in Armed Conflict (2000), Amman Declaration on Child Soldiers (2000), Paris Principles (2007).
} 
"Children shall be special object to respect and shall be protected against any form of indecent assault. The Parties to the conflict shall take all feasible measures in order that children who have not attained the age of fifteen years do not take direct part in hostilities and, in particular, they shall refrain from recruiting them into their armed forces. In recruiting among those persons who have attained the age of fifteen years but who have not attained the age of eighteen years, the Parties to the conflict shall endeavor to give priority to those who are oldest. If arrested, detained or interned for reasons related to the armed conflict, children shall be held in quarters separate from the quarters of adults. The death penalty for an offense related to the armed conflict shall not be executed on person who had not attained the age of eighteen years at the time the offense was committed."

United Nations Convention on the Rights of the Child is another legal document that concerns the prevention of child soldiers. According to Article 38:

"1. State Parties, undertake to respect and to ensure respect for rules of international humanitarian law applicable to them in armed conflicts which are relevant to the child.

2. State Parties shall take all feasible measures to ensure that persons who have not attained the age of fifteen years do not take a direct part in hostilities.

3. State Parties shall refrain from recruiting any person who has not attained the age of fifteen years into their armed forces. In recruiting among those persons who have attained the age of fifteen years but who have not attained the age of eighteen years, State Parties shall endeavor to give priority to those who are oldest.

4. In accordance with their obligations under international humanitarian law to protect the civilian population in armed conflicts, State Parties shall take all feasible measures to ensure protection and care of children who are affected by an armed conflict."

Optional Protocol to the Convention on the Rights of the Child on the involvement of children in armed conflict (OPAC) was adopted in 2000 and entirely focused on child soldiers' issues. According to Article 1 of Protocol, State Parties shall take all applicable amount so that children who have not attained the age of eighteen years do not directly participate in armed conflict. The same case is valid for armed groups other than armed forces by Article 4. Article 3 of the Protocol is about voluntary recruitment in the Army. Although there is no inevitable regulation regarding this issue, determining criteria and principles of the Protocol are listed below:

"1. State Parties shall raise the minimum age for the voluntary recruitment of persons into their armed forces from that set out in Article 38, paragraph 3 of the Convention on the Rights of the Child, taking account of the principles contained in that article recognising that under the Convention persons under the age of 18 years are entitled to special protection.

2. Each State Party shall deposit a binding declaration upon ratification of or accession to the present Protocol that sets forth the minimum age at which it will permit voluntary recruitment into its natural armed forces and a description of the safeguards it has adopted to ensure that such recruitment is not forced or coerced. 


\section{Child soldier realty in Uganda}

3. State Parties that permit voluntary recruitment into their national armed forces under the age of 18 years shall maintain safeguards to ensure, as a minimum, that:

(a) Such recruitment is genuinely voluntary;

(b) Such recruitment is carried out with the informed consent of the person's parents or legal guardians;

(c) Such persons are fully informed of the duties involved in such military service and

(d) Such persons provide reliable proof of age prior to acceptance into national military service.

1997 Cape Town Principles are also emphasised on similar matters. Although the minimumage requirement is set at 18 , according to the Rome Statute of International Criminal Court(ICC), calling children under the age of 15 years to national armed forces, military services or using them actively in any armed conflicts are considered as a violation of applicable laws and as a war crime. However, according to the Elements of Crimes, which was created to assist the court under Article 9 , using and arming children under the age of 15 is a crime against humanity since it constitutes a war crime. There are also records of allegations by the ICC of child recruitment and use in armed conflicts. In 2005, the court issued arrest warrants for the five leaders (Kony, Otti, Odhiambo, Ongwen and Lukwiya) of Lord's Resistance Army for using children as soldiers (Azarkan, 2009: 99); however, proceedings against Lukwiya and Odhiambo were terminated due to their deaths (ICC, No: ICC-02/04-01/05, 2005). Kony is the subject to an arrest warrant by the ICC for war crimes and crimes against humanity such as, murder, sexual slavery, rape, torture and forcing children to participate in the Army. Trial of an ex-child soldier, Dominic Ongwen for war crimes and crimes against humanity, is still ongoing at the International Criminal Court. Ongwen's example shows us the importance of integration of child soldiers back into society; otherwise, as we see in this example, children who grew up in violent environments tend to continue violent actions in adulthood. Trial of the Democratic Republic of the Congo citizen Bosco Ntanganda has opened in 2015 and still ongoing today. Ntanganda had been indicted for recruiting children under the age of 15 years, applying the same harsh military training techniques to children as adults, actively deploying children in armed conflict areas, raping child soldiers and using them as sex slaveries. However, Lubanga's Judgement, the accomplice of Ntanganda, which had concluded in 2012, is a touchstone for child soldiers' protection. Lubanga's case has an essential role since it was the first decision of the ICC, and following this judgment, Lubanga sentenced to 14 years of imprisonment for conscripting and enlisting children under the age of 15 years between the years 2002 and 2003.

The Special Court for Sierra Leone issued its first trial in the case of military use of children and children between the ages of 15 and 18 were tried for their crimes; as a result, these children were sentenced to rehabilitation (Azarkan, 2009: 99).

United Nations Security Council is the most influential body of the United Nations for the maintenance of international peace and security (Kızllsümer Özer, 2016: 211). However, although it was established to protect human rights and this is its primary duty, today, their main duty is to fight against human rights violations because they have a fast decision-making process, and they 
are binding on member countries (Parlak, 2017: 55). They have Security Council decisions for using children as soldiers and apply sanctions to states and groups who use child soldiers. (S/RES/1379). ${ }^{7}$

Another institution worked to prevent exploitation of children is the Coalition to Stop the Use of Child Soldiers, which was established in 1998 by Amnesty International, Human Rights Watch, Save the Children International, Jesuit Refugee Service, Quaker United Nations Office and International Federation Terre des Hommes. Coalition increases the effectiveness of media and universalises Convention on the Rights of the Child with the support of the international public, governments and non-governmental organisations (Child Soldiers International, 2001: 23). In order to accomplish this, researches and observations were carried out in many countries with political instability, especially in Africa (32).

OPAC standards are important to develop because it is based on barring the use of anyone under the age of 18 in conflict. As of 2016, 70 percent of state actors and 60 percent of non-state actors (along with the armed forces) had signed up to the OPAC. For non-state actors cannot use anyone below the age of 18 . More than 30 percent of globally recognised states refused to join the OPAC to prevent exploitation of children for military purposes. In a much-debated decision in 2019, the U.S. secretary of state relinquished the inclusion of Saudi Arabia on its yearly list of countries that use child soldiers, even though it met all the criteria to be included (Middle East Institute, 2020). This is a clear example of an OPAC signatory's failure to comply with the terms of their signed agreements.

\section{Uganda and Child Soldiers}

As stipulated by the Berlin conference, Uganda became a protectorate of the British Empire in 1984. In the continuing process, local organisations were occurred to fight against the Empire's unequal treatments. In 1962 British granted independence to Uganda (U.S.S.R. Academy of Sciences, 1968: 362). In 1971 seizes control of the country after a military coup and nearly 500 thousand people died in the massacres, which led to more vigorous ethnic conflicts day by day (Birmingham, 1995: 45). Uganda's invasion of Tanzania, Britain's support to Tanzania, political instabilities and internal conflicts lead up to local government structures in Uganda. As Ugandan soldiers started to engage in destructive activities such as murder, looting and rape, Acholi people, an ethnic group in Uganda, felt threatened of possible genocidal activities (Amone, 2014: 2). Uganda People's Democratic Army (UPDA) and Holy Spirit Movement have emerged against the threats mentioned above, however, in time, they had evolved into Lord's Resistance Army (LRA), which was founded in 1992 by Joseph Kony. Kony describes himself as a prophet sent by God and claims that he follows the instructions of spirits. The goal of the organisation is to establish a new Christian government based on the Ten Commandments within the states of Uganda, the Democratic Republic of Congo, South Sudan, the Central African Republic and Chad. Kony abducted children to become child soldiers believing that children are more eligible and raised those children as murderers; the Lord's Resistance Army's 90\% were children between the ages of 11 and

\footnotetext{
${ }^{7}$ These decisions are: United Nations Security Council Resolution 1083 (1996), United Nations Security Council Resolution 1261 (1999), United Nations Security Council Resolution 1265 (1999), United Nations Security Council Resolution 1270 (1999), United Nations Security Council Resolution 1460 (2003), United Nations Security Council Resolution 1509 (2003), United Nations Security Council Resolution 1539 (2004), United Nations Security Council Resolution 1612 (2005), United Nations Security Council Resolution 1674 (2006), United Nations Security Council Resolution 1808 (2008), United Nations Security Council Resolution 2051 (2012), United Nations Security Council Resolution 2143 (2014).
} 
16. When a contradiction between Army's actions and ideology burst out, community support has decreased contrary to the support for predecessor organisations Uganda People's Democratic Army and Holy Spirit Movement and the Lord's Resistance Army compensate this decrease by abducting male children and teenagers capable of using guns (Cline, 2003: 120). According to the report published by UNICEF in 2006, between the years of 1986 and 2005, 66 thousand children were abducted by the organisation to become child soldiers. Those children were forced to serve with unconditional obedience to Joseph Kony and other leaders and in case of an escape attempt or disobedience, these children were mutilated or killed (Olsen, 2007: 7-8).

Lord's Resistance Army is known with its crucial activities and implementing horrifying rituals viewed as sacred, such as chopping human parts with "holy" machetes called "Banga". Children were forced to chop body parts of their family members as an obligatory part of their training. Abducted girls were raped and then forced to be sexual slaves. Females were given as rewards to guerillas who serve the organisation's holy aim and depending on the guerilla's rank, these rewards may go up to around 30 women per guerilla. This organisation believes that women are gifted for them by the holy spirit; therefore, when they first enter a region, they share their women with other people. Therefore, this organisation abducts children regardless of gender and as explained above, uses girls for sex slavery. Another mission of girls in the organisation is to carry vital materials from place to place since the organisation was frequently changing locations (Karakaya, 2018: 33). During the war, more than 30,000 children were kidnapped by LRA soldiers and used as child soldiers. Most of them were primary and high school girls. These girls were raped, abused and used as girl soldiers. At the end of war, most of the girls returned to their communities as waif, unskilled and uneducated. Rehabilitation of these former girl soldiers has been effortful, and many social agents are being involved (Ojebode. \& Owacgiu, 2013: 41).

There are numerous researches about their abduction history and their level of post-trauma. They are restricted by the faith on a self-report scale and the small group who filled in the scale. Information about the pre-war status of the children, and family and sociodemographic factors are generally unavailable. In of the researches they interviewed 301 former child soldiers who had been abducted by the northern Ugandan rebellion movement Lord's Resistance Army. All the children were abducted at a young age (9-12 years) and for a long time (approximately 744 days). Almost all the children experienced several traumatic events saw someone being killed, and had to kill someone themselves (Derluyn, at all, 2004: 861). There are so many stories and documentary movies about these ex-combatants. Their stories of abduction are generally identical:

"I was abducted at night from my home on December 26, 1996, by the Lord's Resistance Army. On the way to Sudan, an abducted boy tried to escape. He was recaptured and I had to kill him, by beating him to death with sticks. One day, I was beaten seriously because I dropped a water container during a gunfire. In Sudan, I received military training for 1 month. I learned how to assemble and dismantle a gun. After that, I had to fight both UPDF [Uganda People's Defense Forces] in Uganda and SPLA [Sudan People's Liberation Army] in Sudan. Several times, I went to villages to loot food and abduct other children. One day, I was given to a commander as his wife. I got pregnant and delivered a boy. In a fight with UPDF, I managed to escape, but I had to leave my child in the bush. I don't know what happened to him". (Former Ugandan child soldier; interview in Gulu, Uganda, July 17, 2002 via Derluyn at all., 2004: 863) 
Betty Ejang was 13 years old when she was abducted. She was one of Joseph Kony's 'wives' for four years before finally escaping.

"Some of us were ordered to help kill my friend who was overheard talking about escaping, we were asked to each pick a different part of her body, like the arm. They then gave us machetes and told us to cut it into pieces. I really cried because she was my friend but if I had refused, they would have killed me." (Al Jazeera Magazine, 2015)

There are some few former child soldiers who are now leading very productive lives. After escaping from captivity, Omony (now 33 years old) received psychosocial support at World Vision Trauma Counselling Centre in Gulu town. (D+C, 2017):

"Talking about my past brings back painful memories. Usually, I focus on my business and family to overcome the traumatic experiences inside the LRA camp and witnessing the gruesome killings."

Also, it must be stated that according to the data of Human Rights Watch's, not only the Lord's Resistance Army but also the Ugandan Government use child soldiers. Children who serve in local forces join the Ugandan Army after their military training to fight against Lord's Resistance Army (HRW, 2003: 45). It is reported that in 2002 a 12 years old child joined the Army (HRW, 2003: 45). The conflict between the Lord's Resistance Army and the UPDF in northern Uganda resulted in camps of over 1.5 million northerners being locked up in the turn of the 2000s. This population, which owed its survival to low rations of humanitarian aid, has also been a constant target of attacks by the LRA, known for its systematic policy of kidnapping children and adolescents (Dolan, 2009).

Lord's Resistance Army forces left Uganda in 2006 and after the decisions of truce, some of the children have run away and the organisation has released some of them. However, the issue of reintegrating children who had witnessed so much violence in a brutal organisation into society became the main topic of international conversations. Between 1986 and 2006 the Northern Uganda region has been the location of a twenty year internal conflict between the LRA and the Ugandan national government. Early on the LRA and other insurgent groups with some popular recognition claimed to fight against the marginalisation of the Northern Ugandan area, in the course of the internal conflict the civilian inhabitants became the major target group of the insurgent assault that also included as a battle strategy the kidnapping of children and youth for later inclusion as child soldiers, especially for girls sexual slaves, into the LRA. Since the beginning of the conflict, different numbers of groups of the population have been forced to be internally displaced. Since 1996, the internal conflict continued, although the national government armed forces implemented a mandatory "protective displacement" policy to prevent further insurgency attacks in the sparsely populated area. It is estimated that at least $90 \%$ of the population was displaced in 2005. (Whitmore, 2010; Temmerman, 2009).

\section{Reintegration of Child Soldiers into Society in Uganda}

Studies of child soldiers are very few in number and are largely based on the case and interviews with former participants (Blattman \& Annan, 2008: 123). According Blattman and Annan, 'Uganda is an unusual but important place to evaluate the impacts of child and youth soldiering and the meaning of reintegration' (2008: 125). Thousands of civilians have been forcibly 
conscripted by the insurgent LRA, over two decades of war- $2 / 3$ of them children under the age of 18 .

After the Lord's Resistance Army, most of whom were children, began withdrawing its Army from Uganda, the unknown future of children became an important topic of debate. There were many questions about how to shelter children who have injured during the armed conflicts after their treatments because most of these children were lost their families during armed conflicts. The government tried to solve this issue by placing children into orphanages and assumed moral and national duty to ensure that they do not have an uncertain future (Kayihura, 2000: 11). According to a research with mothers of child soldiers in Uganda, there is a procedure for rescued children, who experience problems such as basic needs, inability to integrate into daily life and exclusion, to help them get back to their daily lives (Carter, 2014: 358). DDR (disarmament, demobilisation and reintegration) programs are operationalised unofficially for their rehabilitation and reintegration; the main purpose of the program is to provide children the life they deserve far from exploitation. During this process, children are kept away from hostilities, get psychosocial support and reunified with their families. The results are disputable, but the DDR program was certainly applied to exLRA members non-systematically and unofficially. Also, children who suffered from war and grew up with this experience would not feel unidentified; thus, Kadago schools, which provide special education, were opened for them to avoid their exclusion from society, monotonous school life and to prevent demoralisation. Another reason to isolate these children is that the Ugandan community believed that ex-LRA member children deserve the same punishments as adults and the children known as child soldiers faced the problem of getting labeled in society.

After students pass the first grade in Kadago schools, they take the PLCE (Primary Leaving Certificate Examination) exam and those who succeed get the chance to continue their second-grade education in private schools. 4.514 child soldiers benefited from the learning experience in Kadago schools between the years 1999 and 2006 (Etyang, 2010: 74). If war-exposed children refuse to continue their education, non-governmental organisations train them for specific skills.

Table 2. Educated Child Soldiers in Uganda in 2007

\begin{tabular}{lcc}
\hline LEVEL & NUMBER & RATE \\
\hline PRIMARY S. & 500 & 43 \\
\hline LEVEL “O" & 250 & 22 \\
\hline LEVEL "A" & 100 & 9 \\
\hline UNIVERSITY & 45 & 4 \\
\hline OTHER & 264 & 22 \\
\hline Total & 1159 & 100 \\
\hline
\end{tabular}

Source: Ministry of Education in Uganda Official Website

\section{Joint Programme by Uganda Local Forces with UN and Other NGOs}

Local governments do not implement the United Nation's protocols and regulations in most African countries. Since the sanctions are ignored and arms sale continued in countries, implementations of UN resolutions remain incapable. Many international NGOs continue their educational and awareness-raising activities in the area with the support of the UN. While the United Nations was holding its fourth open discussion on children and armed conflicts, Stop The Use of 
Child Soldiers Coalition pointed out that child soldier use continues at the same pace. The coalition called on the UN Security Council to take action against the recruitment of child soldiers.

"Stop The Use of Child Soldiers Coalition" was formed by different coalitions from Africa, Asia, Europe, Latin America and local and international organisations from the Middle East and the founding members of the Coalition are Amnesty International, Defense for Children International, Human Rights Watch, International Federation Terre Des Hommes, International Save the Children Alliance, Jesuit Refugee Service, Quaker UN Office(Geneva) and World Vision International.

The most effectual institution examining Uganda and other countries using child soldiers is the Romeo Dallaire Child Soldiers Initiative situated at Canada Dalhousie University (Dallaire, 2017). This initiative aims to provide necessary tools and information to the Uganda People's Defense Force to prevent the use of children as soldiers as part of the National Education Programme. The main aim of the trainings given since 2015 is to educate military forces and especially women in military forces. In this program, 20-woman security officers, 26 cops and 9 prison staff go through these trainings such as workshops for executives and trainings for trainers (Whitman et al., 2016).

Even though many governments had supported United Nation's convention to prevent child soldiers, NGOs demanded child soldier recruitment to ban and rehabilitation programs were established, expected progress could not be achieved due to governments' failure to fulfill their obligations. Even though the UN Security Council has made astonishing statements on child soldiers and conducts prevention works, some members head concrete punishments against those who break the agreements off. In order for these civilian initiatives to work in the long term, the UN Security Council has to implement concrete sanctions and ensure that those who use children as soldiers to be indicted in the International Criminal Court.

\section{Conclusion}

The reality of child soldiers is an undeniable truth encountered all around the world. Both compulsory or voluntary armed children may have criminal tendencies if they are not reintegrated into society, whether through education or other efforts after leaving the armed forces. Therefore, the reintegration of child soldiers is still an important issue today. It is an urgent need that a comprehensive oversight unit should prioritise multiple needs, channel funding to the most instant problems faced by child soldiers, and provide counseling, rehabilitation and rehabilitation, especially to former child soldiers for their return to society. It is clear that this will be a multi-year effort.

International legal documents to prevent any actions regarding the use of children as soldiers are not sufficient to find a solution. The main reason for this is that these actions are seen in a secondary position. In international judicial decisions, the issue, as mentioned earlier, is taken into consideration from international public opinion in the 21st century. During the Second World War, although there is sufficient evidence of the use of children as soldiers, in Yugoslavia and Ruanda, the judiciary decisions were pale in comparison. Especially in Yugoslavia, witnesses and evidences show that girls were used as sex slaves and forced into prostitution. Therefore, criminal offenders are aware that they will not be punished by their actions and do not hesitate to use children as soldiers. Lord's Resistance Army is the most aggravating example of this use. It is not the right approach to label those children who are being used for military purposes as offenders; at this point, it should be considered that if the children are old enough to realise the situation. 
An important step towards reducing the use of child soldiers is to find a global solution with all recognised countries to sign the OPAC. Prominent state actors who continue to pay for children or recruit them should be sanctioned. OPAC signatories should then put pressure on semi-state actors who always receive support from state actors. Civil society and NGO's should embarrass state actors for indirectly supporting child soldiers, while governments should impose sanctions on their representatives to end child abuse.

DDR program of Uganda, a special education system designed for the reintegration of ex-child soldiers into society, is an essential step in the right direction, but it is not enough. To reintegrate child soldiers into society, children must be part of a loving family rather than being raised isolated from society and easily forget the overtones of war. Also, assigning the responsibility of the reintegration process to NGOs and the Commission of Trust is not enough. The government needs to prepare a full-fledged program to envisage this process, which will both be an example for other countries and speed up the reintegration process of children. If the revisions, as mentioned above, were not made, children who are used as soldiers will cause more significant problems in their adulthoods, and as seen in the example of Dominic Ongwen, children who grew up in a violent environment interiorise violence and continue to take similar actions. The international community has to work effectively on this ongoing and unsolved issue to seek permanent solutions under international law.

\section{References}

Aktaş Ö. ve Safran M. (2012). Savaş ve Tarih, Milli Eğitim Dergisi, 42(196): 246-257.

Al Ibrahim, D. (2020) "Cubs of Caliphate: Analysis of Children'Images in ISIS Visual Propaganda". International Journal of Media Science Works, Vol. 07, Issue 08, PP. 01-07, August 2020.

Al Jazeera Magazine (2015). The Girls of the LRA. https://www.aljazeera.com/features/2015/05/29/magazine-the-girlsof-the-lords-resistance-army/, online 0-04-2020.

Allen, T. (2005). War and Justice in Northern Uganda: An Assessment of the International Criminal Court's Intervention. London: Crisis States Research Centre, Development Studies Institute, London School of Economics.

Amone C. (2014). Rejecting the Masculinity of War: Was Alice Auma Lakwena of the Holy Spirit Movement the Messiah of the Acholi. Journal of Human and Social Science Research, C. IV.(1): 1-7.

Aydın D. (2002). Suç Unsurları. Ankara Üniversitesi Hukuk Fakültesi Dergisi, 51(4): 131-167.

Aydın H.\& Gündüz V. (2010). Çocuk Güvenliğinin Sağlanmasında Yerel Yönetimlerin Rolü: “Uluslararası Hukukta Taş Atan Çocuklar" Sorunu. Türk İdare Dergisi, 468: 9-31.

Birmingham D.(1995). The Decolonisation of Africa. Ohio: Ohio University Press.

Blattman, C., \& Annan, J. (2008). "Child combatants in northern Uganda: Reintegration myths and realities", in Security and Post-Conflict Reconstruction (pp. 123-145). Routledge.

Cline L.E. (2003). Spirits and the cross: religiously based violent motivations in Uganda. Small Wars \& Insurgencies, C. XIV(2): 113-130.

Çocuk Haklarına Dair Sözleşmeye Ek Çocukların Silahlı Çatışmalara Dâhil Olmaları Konusundaki Seçmeli Protokol. (2004, 2 Mart). Resmi Gazete (Say1: 2004/6938). Access Address: https://www.ombudsman.gov.tr/contents/files/ 6314-- Cocuk-Haklarina-Dair-Sozlesmeye-Ek-Cocuklarin-Silahli-Catismalara-Dahil-Olmalari-KonusundakiSecmeli-Protokol.pdf

D + C (2017). https://www.dandc.eu/en/article/former-child-soldier-uganda-managed-become-successful-businessman, online 05-04-2020.

Derluyn, I., Broekaert, E., Schuyten, G., \& De Temmerman, E. (2004). Post-traumatic stress in former Ugandan child soldiers. The Lancet, 363(9412), 861-863.

Dolan, C. (2009). Social Torture. The Case of Northern Uganda, 1986-2006, Oxford \& New York, Berghahn Books.

Etyang O. (2010). Reintegration of Child Soldiers in Africa: A Case Study Of Uganda (Yüksek Lisans Tezi, Nairobi Universitesi). Access Address: http://erepository.uonbi.ac.ke/handle/11295/20078

Global Security. Lord's Resistance Army. Access Address: https://www.globalsecurity.org/military/world/para/lra.htm 
Human Rights Watch. Child Soldier Use 2003. Access Address: https:/www.hrw.org/sites/default/ files/reports/childsoldiers.pdf

Human Rights Watch. Child Soldiers. Access Address: https://www.hrw.org/topic/childrens-rights/child-soldiers

Human Trafficking Center. Child Soldiers. Access Address: http://humantraffickingcenter.org/difficulties-in-reintegrating-ugandas-child-soldiers/

ICC. The Prosecutor v. Bosco Ntaganda. ICC-01/04-02/06. Access Address: https://www.icc-cpi.int/drc/ntaganda/ Documents/NtagandaEng.pdf

ICC. The Prosecutor v. Dominic Ongwen. ICC-02/04-01/15. Access Address: https://www.icc-cpi.int/uganda/ongwen/ Documents/OngwenEng.pdf

ICC. The Prosecutor v. Thomas Lubanga Dyilo. ICC-01/04-01/06. Access Address: https://www.icc-cpi.int/drc/ lubanga/Documents/LubangaEng.pdf

ICC. The ProsecutorJoseph Kony and Vincent Otti: Alleged Crimes (Non-Exhaustive List). No:

ICC-02/04-01/05. Access Address: https://www.icc-cpi.int/CaseInformationSheets/KonyEtAlEng.pdf

ICRC. Convention (IV) respecting the Laws and Customs of War on Land and its annex: Regulations concerning the Laws and Customs of War on Land. Access Address: https://ihl-databases.icrc.org/ihl/INTRO/195

ILO. (2003). Wounded Childhood: The Use of Child Soldiers in Armed Conflict in Central Africa. Washington: International Labor Organization.

ILO. (2013). Wounded Childhood: The Use of Child Soldiers in Armed Conflict in Central Africa. Access Address: https://www.ilo.org/wcmsp5/groups/public/---ed_emp/---emp_ent/--ifp_crisis/documents/publication/wcms_116566.pdf

Karakaya B.B. (2018). Tanrı'nın Direniş Ordusu (LRA) ve Uganda Dış Politikasına Etkisi, Ankara: Ankara Üniversitesi Sosyal Bilimler Enstitüsü. Yayımlanmamış Yüksek Lisans Tezi.

Kayihura K. (2000). Uganda: The Integration of Child Soldiers Into The School System. Access Address: http://www.adeanet.org/clearinghouse/sites/default/files/docs/adea_00_uganda_en.pdf

Kızılsümer Özer D. (2006). İnsan Haklarının Birleşmiş Milletler'in Kurumsal Yapısı İçinde Korunması. Dokuz Eylül Üniversitesi İsletme Fakültesi Dergisi, 17(2): 205-234.

Kocatepe A. (2009). Silahlı Çatışma Hukuku Açısından Cenevre Sözleşmeleri ve Ek Protokolleri El Kitabı, İstanbul: Harp Akademileri Komutanlı̆̆ 1 Yayınları.

Kolb, R. (1997). "Origin of the twin terms jus ad bellum/jus in bello. International”, Review of the Red Cross Archive, 37(320), 553-562.

Middle East Institute, 2020Child Soldier Number Doubled Middle East Adress: https://mei.edu/publications/beginchildren-child-soldier-numbers-doubled-middle-east-2019, online 10-10-2020

Ministry Education in Uganda, Access Address: http://www.education.go.ug/files/downloads/Headcount\% 20Report\%202016.pdf

Newman C. (2014). No One To Stand By Us: Reintegrating Formerly Abducted Child-Mothers in Uganda. Journal of Intervention and Statebuilding. 8: 357-380.

Ojebode, A., \& Owacgiu, J. A. (2013). Never again say 'land': Understanding media silence on post-war conflicts in Northern Uganda. Journal of Communication and Language Arts, 4(1), 37-61.

Olsen K.T. (2007). Violence Against Civilians In Civil War: Understanding Atrocities by The Lord's Resistance Army In Northern Uganda, Conflict Research Group, Working Paper No. 8.

Papiroom, Access Address: https://www.papiroom.net/505654545353_afrikada-hacli-teror-orgutu-lra

Parlak T.M. (2017). Uluslararası Hukukta Silahlı Çatışmalarda Kadınların Korunması. İstanbul: On İki Levha Yayıncilik.

Parlak T.M. (2015). Galiplerin Adaleti: Nürnberg ve Tokyo Askeri Ceza Mahkemeleri, İstanbul Aydın Üniversitesi Anadolu Bil Meslek Yüksekokulu Dergisi, 38: 37-53.

Roma Statue. Access Address: https://www.tbmm.gov.tr/komisyon/insanhaklari/mevzuat_CDRS.htm

Temmerman, E. D. (2009) Aboke Girls: Children Abducted in Northern Uganda. Kampala: Frontiers Publishers

Topal A. H. (2009). Uluslararası Ceza Yargılamalarında Cinsel Suçlar. İstanbul: On İki Levha Yayıncılık.

U.S.S.R. Academy of Sciences (1968). A History of Africa, Moskova: Nauka Publishing House.

UN. Convention on the Rights of the Child. Access Address: https://www.ohchr.org/en/professionalinterest/ pages/crc.aspx

UNICEF. Factsheet: Children Associated With Armed Groups and Forces Central Africa. Access Address: http://www.unicef.org/wcaro/FactSheet100601Final_E_100603_.pdf

UNICEF. Uganda. Erişim adresi: https://www.unicef.org/uganda/

Wessells, M. (2006). Child Soldiers: From Violence to Protection. Cambridge: Harvard University Press. 
Whitmore, T. D. (2010a) "Genocide or Just Another "Casualty of War"? - Part I The Interpretive Context of Intrigue." Practical Matters 3, Fall 2010; 1-49 